Ramskyi, A., Sobolieva-Tereshchenko, O. and Zharnikova, V. (2019) "Comparison worldwide and Ukrainian practice of bank stress testing”, Management and entrepreneurship: trends of development, 4 (10), pp. 19-28. Available at: doi: https://doi.org/10.26661/2522-1566/2019-4/10-02

FINANCE, BANKING AND INSURANCE

Received:

8 October, 2019

1st Revision:

12 November, 2019

Accepted:

DOI https://doi.org/10.26661/2522-1566/2019-4/10-02

15 November, 2019

\title{
COMPARISON WORLDWIDE AND UKRAINIAN PRACTICE OF BANK STRESS TESTING
}

\author{
Andrii Ramskyi \\ Boris Grinchenko University \\ Kyiv, Ukraine \\ ORCID: 0000-0001-7368-697X
}

\author{
Olena Sobolieva-Tereshchenko \\ Boris Grinchenko University \\ Kyiv, Ukraine \\ ORCID: 0000-0002-1086-1192
}

\author{
Valeriia Zharnikova \\ Kyiv National University of \\ Trade and Economics \\ Kyiv, Ukraine \\ ORCID: 0000-0002-4335-5149
}

*Corresponding author email: o.tereshchenko@kubg.edu.ua

\begin{abstract}
Early stress tests, used primarily as risk management tools, date back as far as the 1990s. Programs conducted by the IMF, Bank of England, Dodd-Frank Act, Bank of Japan, Swiss Financial Market Supervisory Authority and the World Bank promoted the used of stress tests. The basic idea the introduction of stress testing was to ensure that banks have sufficient capital to cover their risks, and to ensure that banks and banking systems are more resilient to economic and financial shocks. This paper provides an overview of the recent implementation of stress testing by regulatory agencies in the United States, the United Kingdom, Japan, Switzerland and the European Union. This article also gives an overview of the stress testing methodology developed by the National Bank of Ukraine and in accordance with Basel III recommendations. The aim of research is comparative evaluation of key aspects of system-wide stress tests in different finance systems: Euro area, United Kingdom, Switzerland, Japan, the United States and Ukraine, identifying identification of similarities and differences and prospects for the development in our country. To substantiate the theoretical positions and reasoning of the conclusions general scientific methods are used, including system, abstract-logical approach, as well as methods of formalization, analysis and synthesis of information, comparative analysis. During the study, a comparative analysis of the stress-testing methodology in six countries was conducted. The scientific importance of the work lies in the fact that on the basis of the conducted research it is possible to improve stress-testing of Ukrainian banking system based on best practices from developed countries. The value of the research is that it is increasingly necessary to used best practices of stress tests as a powerful tool in risk management, in micro prudential and macroprudential policies. Results of researches can to used not only in development methodology of stress-testing, but also in case-study of banking.
\end{abstract}

Key words: financial stability, Basel III, core capital, regulatory capital

JEL Classification: E37, E44, G10, G21, G28

\section{INTRODUCTION}

The Basel Committee on Banking Supervision (BCBS) requires banks to conduct their own stress tests as an important risk management tool, earning bank management to adverse unexpected outcomes related to various risks and estimating capital that may be needed to weather a storm (BIS 
Working Paper, 2009). Additionally, in Worldwide practice, stress tests came to be recognized as a powerful tool not only in risk management, but also in micro prudential and macroprudential policies. Despite the existence of studies of stress testing programs in various countries, few studies have been conducted on their comparative evaluation. This paper is one of the few studies.

\section{LITERATURE REVIEW}

The issues of assessing the financial stability of a banking system are studied by a sufficient number of foreign and domestic scholars. In particular, foreign experts as Frame, Scott, Kristopher Gerardi, and Paul Willen (2015), Hirtle, Beverly, Anna Kovner, James Vickery, and Meru Bhanot (2016) effectively described research of the top-down methodologies, which actually applied to stress testing. The research on the bottom-up methods is limited but the models used at regulatory agencies still use "extreme yet plausible" exogenous macroeconomic scenarios to obtain stressdriven results using the loan-level data.

The policy of the stress-testing in the US, the UK, and the EU area wide describes in researches Wall, Larry (2014), Goldstein, Morris (2017), Kapinos, Pavel, Oscar Mitnik, and Christopher Martin (2018).

Domestic researchers in the sphere of risk management and in particular in the field of stress testing are represented by such scientists as I. M. Posokhov, O.O. Khodyreva (2018), Ramskyi A., Loiko V., Sobolieva-Tereshchenko O., Loiko D., Zharnikova V. (2017), Krykliy O., Luchko I., (2018). However, the fact that the use of stress testing is not wide-spread, makes it possible to judge about certain problems of the adaptation of the proposed methods to the current realities of the banking sector of the Ukrainian economy.

The purpose of the article is the study of special features and approaches to conducting stress testing of the banks in Ukraine, in the comparison with Worldwide practice.

\section{PAPER OBJECTIVE}

The stress tests as a powerful tool in risk management, in micro prudential and macroprudential policies is important direction of the world economy financial stability. The purpose of the article is identifying of similarities and differences of system-wide stress tests in finance systems Euro area (EU), United Kingdom (GBR), Switzerland (CHE), Japan (JPN), the United States (USA), Ukraine (UA) and determining prospects for the financial stability improvements in our country.

\section{RESULT AND DISCUSSION}

The purpose of stress testing is to assess to what extent an individual bank, group of banks or the banking system as a whole are resistant to exceptional, but plausible shocks. Stress tests are aimed at determining the sensitivity of a bank's portfolio or the whole banking system to negative shocks, carrying out a forecast impact assessment of the effects of these shocks on financial indicators and capital of banks, and further defining measures to enhance the resilience of the banking system to such shocks.

The comparison of country practices showed that authorities design stress tests in different ways, additionally some employing more than one type of test. For better understand these differences and their fitches covered practices on system-wide stress tests for banks in the Euro area, United Kingdom, Switzerland, Japan and the United States. In general, a stress test is composed of various modelling blocks, which interact with one another to produce the overall results. The practices on system-wide stress tests has been researched in the few main blocks, which identifies in the setup of any stress test. These blocks are governance (essence and coverage of 
Ramskyi, A., Sobolieva-Tereshchenko, O. and Zharnikova, V. (2019) "Comparison worldwide and Ukrainian practice of bank stress testing”, Management and entrepreneurship: trends of development, 4 (10), pp. 19-28. Available at: https://doi.org/10.26661/2522-1566/2019-4/10-02

exercise), implementation (scenario and disclosure). Each block comprises various elements, they are detailed in the tables below. The essence and coverage of exercise in system-wide stress tests for banks in the Euro area, United Kingdom, Switzerland, Japan, United States and Ukraine are summarized in table 1 .

Table 1

Comparison of key aspects of system-wide stress tests (ST)

\begin{tabular}{|c|c|}
\hline \multicolumn{2}{|r|}{ GOVERNANCE (ESSENCE AND COVERAGE OF EXERCISE) } \\
\hline \multicolumn{2}{|r|}{ Essence } \\
\hline EU & Bottom-up micro prudential exercise using individual bank data to primarily assess solvency risk. \\
\hline GBR & $\begin{array}{l}\text { Bottom-up micro prudential exercise. Banks submit their projections, Bank of England uses those } \\
\text { submissions as a starting point for the stress test, with its own adjustments. }\end{array}$ \\
\hline $\mathrm{CHE}$ & $\begin{array}{l}\text { Top-down exercise mainly to assess the solvency risk of the two Swiss global systematically important } \\
\text { banks and bottom-up micro prudential exercise using individual bank data and bank-internal models. }\end{array}$ \\
\hline JPN & $\begin{array}{l}\text { Top-down exercise using individual bank data, mainly to assess solvency risk. Bottom-up exercise for } \\
\text { micro prudential risk assessment and for financial stability risk assessment for a macroprudential } \\
\text { perspective. }\end{array}$ \\
\hline USA & $\begin{array}{l}\text { Dodd-Frank Act Stress Test top-down micro prudential exercise using individual bank and industry level } \\
\text { data to assess the impact of stressful economic and financial market conditions on the solvency of banks } \\
\text { with } \$ 100 \text { billion or more in total assets. }\end{array}$ \\
\hline UA & $\begin{array}{l}\text { Bottom-up micro prudential exercise using individual bank data. Individual stress-testing assessment of } \\
\text { large exposures and portfolio- based assessment for other. }\end{array}$ \\
\hline \multicolumn{2}{|r|}{ Coverage of exercise } \\
\hline EU & $\begin{array}{l}\text { Institutions } 123 \text { banking groups from } 22 \text { countries Sample of banks covering at least } 50 \% \text { of the national } \\
\text { banking sector in each EU Member State in terms of total assets. }\end{array}$ \\
\hline GBR & $\begin{array}{l}\text { Include all PRA-regulated banks and building societies with total retail deposits greater than } £ 50 \text { billion. } \\
\text { Institutions } 7 \text { major UK banks and building societies }\end{array}$ \\
\hline $\mathrm{CHE}$ & $\begin{array}{l}\text { Banks covered represent roughly about } 80 \% \text { of total assets in the Swiss banking sector and covers two } \\
\text { Swiss G-SIBs on the basis of their systemic relevance to the global financial system and the Swiss } \\
\text { economy. }\end{array}$ \\
\hline JPN & $\begin{array}{l}\text { Covers a total of roughly } 370 \text { financial institutions, G-SIBs banks (roughly about } 70 \% \text { of total assets in } \\
\text { the banking sector), small community orientated banks, representing roughly } 80 \text { to } 90 \% \text { of total credit } \\
\text { outstanding. }\end{array}$ \\
\hline USA & $\begin{array}{l}35 \text { banks represent approximately } 80 \% \text { of domestic bank assets. Among them, } 6 \text { banks with large trading } \\
\text { operations and } 8 \text { banks with substantial trading or processing operations. } 31 \text { holding companies with } \\
\text { total assets of } \$ 50 \text { billion. }\end{array}$ \\
\hline UA & $\begin{array}{l}34 \text { banks, } 79 \% \text { of assets in } 2014,20 \text { of the largest banks in } 2017,25 \text { banks, } 93 \% \text { of assets in } 2018,24 \\
\text { banks, } 90 \% \text { of assets in } 2019,29 \text { banks, } 93 \% \text { of assets in } 2020\end{array}$ \\
\hline
\end{tabular}

Source: compiled by the authors according to the ST source (EU, GBR, CHE, JPN, USA, UA).

Typically, coverage of exercise in stress testing, which of the supervisory authority or the central bank represent roughly $80 \%$ of the total bank's assets. However, in each case, the central bank and supervisors run a stress test exercise different number of institutions (for example, in UK 7 major banks and building societies, in Euro area in 123 banking groups from 22 countries).

As a rule, the supervisor or the central bank conduct stress testing. In some countries, the central bank and supervisors both run a stress test exercise, but independently of each other, with the central bank taking a mainly macroprudential perspective, and the supervisory authority primarily a micro-prudential (for example, Switzerland and Japan).In other countries, the systemwide exercises are run by a single authority, which assumes both micro- and macroprudential functions (for example, Euro area, United Kingdom and United States). According to BCBS (2017), most supervisory authorities do not have a formal process for coordinating supervisory stress testing frameworks with other domestic authorities. 
The number of banks covered and the overall share of total banking assets they represent; resources, both in terms of number of staff and their technical skills; data accessibility and access are crucial. Resources that can be devoted to stress exercises can impact sample coverage, the number of stress scenarios and modelling approaches.

The scenario and disclosure of exercise in system-wide stress tests for banks in the Euro area, United Kingdom, Switzerland, Japan, United States and Ukraine are summarized in table 2.

Table 2

\section{Comparison of key aspects of system-wide stress tests (ST)}

\begin{tabular}{|c|c|}
\hline \multicolumn{2}{|r|}{ IMPLEMENTATION (SCENARIO AND DISCLOSURE) } \\
\hline \multicolumn{2}{|r|}{ Scenario } \\
\hline EU & One adverse scenario as well as a common baseline scenario \\
\hline GBR & $\begin{array}{l}\text { Baseline scenario, annual cyclical scenario, and an additional scenario intended to probe the resilience of } \\
\text { the system to risks }\end{array}$ \\
\hline CHE & $\begin{array}{l}\text { Consists of a baseline and multiple stress scenarios (in the range of } 3 \text { to 5), which are evaluated in } \\
\text { parallel, in order to avoid ex ante focus on a specific stress scenario. }\end{array}$ \\
\hline JPN & $\begin{array}{l}\text { Two stress scenarios are compared against a baseline scenario: a "tail event" scenario, assessing the } \\
\text { stability of the banking system under severely adverse economic and financial conditions, and a "tailored } \\
\text { event" scenario, which to investigate the vulnerability of the financial system under specific } \\
\text { circumstances. }\end{array}$ \\
\hline USA & $\begin{array}{l}\text { Consists of one baseline and two adverse scenarios (adverse and severely adverse). The scenarios are } \\
\text { based on narratives published by the Federal Reserve and the baseline scenario does not represent } \\
\text { official forecasts. }\end{array}$ \\
\hline UA & $\begin{array}{l}\text { In } 2014 \text { two stress scenarios: baseline and pessimistic, during 2015-2017 baseline and macroeconomic } \\
\text { scenarios, after } 2018 \text { - baseline and adverse scenarios }\end{array}$ \\
\hline \multicolumn{2}{|r|}{ Disclosure } \\
\hline EU & $\begin{array}{l}\text { Banks have access to the assessment of their results during the QA phase, their final results are made } \\
\text { public. Banks and the public get the same information, i.e. euro area level results with no country- } \\
\text { specific or bank-specific results released. }\end{array}$ \\
\hline GBR & $\begin{array}{l}\text { Detailed disclosure of aggregate bank results (consolidated for the whole banking sector), capital-ratio } \\
\text { data on individual banks. }\end{array}$ \\
\hline CHE & $\begin{array}{l}\text { Neither the scenarios nor the results of the exercises themselves are disclosed in quantitative terms to } \\
\text { banks or the public. Results of the exercise are summarized in qualitative terms and disclosed to } \\
\text { participating banks only, not to the public. }\end{array}$ \\
\hline JPN & $\begin{array}{l}\text { Results are publicly disclosed with no difference in disclosure between the banks and the public. Results } \\
\text { of the exercise is to benchmark against individual banks' stress test results from a micro prudential } \\
\text { perspective. }\end{array}$ \\
\hline USA & $\begin{array}{l}\text { Both post-stress capital ratios and adjust them planning capital distributions are publicly disclosed at } \\
\text { bank level. Also, information about its scenario design framework and detailing materials about model } \\
\text { changes are published. }\end{array}$ \\
\hline UA & $\begin{array}{l}\text { In } 2014 \text { not made public, during } 2015-2017 \text { public only participating banks public, after } 2018 \text { - public } \\
\text { with no difference in disclosure between the banks and the public. }\end{array}$ \\
\hline
\end{tabular}

Source: compiled by the authors according to the ST source (EU, GBR, CHE, JPN, USA, UA).

The script can be developed in at least three different ways. The first approach is to focus on macroeconomic variables. This requires the inclusion of shocks in some key macroeconomic variables (for example, asset prices, unemployment) that suffered the most during a recession. Shocks for other macro-financial variables are set consistently in terms of magnitude and direction, also in accordance with the narrative. The second approach to determining the shocks underlying the scenario is to obtain them by aggregating information about individual bank portfolios and the corresponding granular risk factors. This approach is typically used in bottom-up stress tests, and its applicability largely depends on the availability of relevant data. The third approach is reverse stress testing, in which the scenario is calibrated in such a way as to provide a given estimated probability 
Ramskyi, A., Sobolieva-Tereshchenko, O. and Zharnikova, V. (2019) "Comparison worldwide and Ukrainian practice of bank stress testing”, Management and entrepreneurship: trends of development, 4 (10), pp. 19-28. Available at: https://doi.org/10.26661/2522-1566/2019-4/10-02

or the expected capital ratio after stress (for example, Breuer et al (2010)). While useful for identifying additional vulnerabilities in the future, this approach is difficult to implement and interpret (for example, due to the diversity and complexity of the interactions between types and risk factors).

The publications on the results of the stress testing exercise are very important for used as a risk management tool and an instrument of informing about business decisions. In most cases, information about stress testing results disclosure consolidated for the whole banking sector and summarized in qualitative terms. Usually, the results of the macroprudential stress testing are publicly disclosed with no difference in disclosure between the banks and the public. More disclosure information in Euro area and little disclosure information in Switzerland: in Euro area banks and the public get the same information with no country-specific or bank-specific results released. Traditionally, in Switzerland results of the stress testing exercise are only disclosed to participating banks, not to the public.

In Ukrainian practice, NBU disclose results of stress testing exercises and high-level methodologies and scenario specifics. In addition to disclosure by the authorities, the banks themselves can also decide to publish their results. The integration of Ukraine into the European banking system requires implementation effective tool for cleaning the Ukrainian banking system in accordance with compliance with the Basel III regulations. Since 2015 according to level disclosure stress testing exercise in Euro area Ukraine started to publish their results.

The macroeconomic stress testing of the Ukrainian banking system was first carried out in 2008 (with the participation of 17 banks), then in 2010. However, the results of these tests were not made public. We only know that the capital of 61 out of 176 banks had to be increased by a total of 40 billion UAH. However, the need for active use of stress-testing process arose in early 2014 due to a number of internal and external factors. Approaches to stress testing in the period from 2014 to 2020 are presented in Table 3.

Table 3

History of stress testing of Ukrainian banking system

\begin{tabular}{|c|c|c|c|c|c|c|}
\hline \multirow{2}{*}{ Indicators } & \multicolumn{6}{|c|}{ Stress testing } \\
\hline & 2014 & $2015-2016$ & 2017 & 2018 & 2019 & 2020 \\
\hline Auditors & $\mathrm{AC}$ & NBU & NBU & $\mathrm{AC}, \mathrm{NBU}$ & $\mathrm{AC}, \mathrm{NBU}$ & $\mathrm{AC}, \mathrm{NBU}$ \\
\hline $\begin{array}{l}\text { Date of } \\
\text { diagnosis } \\
\text { evaluation }\end{array}$ & 01.01 .14 & $\begin{array}{l}01.04 .15, \\
01.01 .16, \\
01.04 .16\end{array}$ & 01.01 .17 & 01.01 .18 & 01.01 .19 & 01.01 .20 \\
\hline $\begin{array}{l}\text { Individual } \\
\text { stress test }\end{array}$ & No & $\begin{array}{c}\text { large } \\
\text { borrowers }\end{array}$ & $\begin{array}{c}\text { large } \\
\text { borrowers }\end{array}$ & $\begin{array}{c}\text { large } \\
\text { borrowers }\end{array}$ & large borrowers & $\begin{array}{c}\text { large } \\
\text { borrowers }\end{array}$ \\
\hline $\begin{array}{l}\text { Portfolio } \\
\text { stress test }\end{array}$ & Loans & Loans & Loans & Loans & Loans & Loans \\
\hline $\begin{array}{l}\text { Risks that } \\
\text { are being } \\
\text { analyzed }\end{array}$ & $\begin{array}{l}\text { Credit, } \\
\text { currency }\end{array}$ & $\begin{array}{l}\text { Credit, } \\
\text { currency }\end{array}$ & $\begin{array}{l}\text { Credit, } \\
\text { currency }\end{array}$ & $\begin{array}{l}\text { Credit, } \\
\text { market }\end{array}$ & $\begin{array}{l}\text { Credit, interest, } \\
\text { currency }\end{array}$ & $\begin{array}{l}\text { Credit, } \\
\text { interest, } \\
\text { currency }\end{array}$ \\
\hline Result & $\begin{array}{c}9 \text { banks } \\
\text { passed } \\
\text { stress } \\
\text { testing. } \\
\text { Need of } \\
\text { capital }>50 \\
\text { billion UAH. }\end{array}$ & $\begin{array}{c}34 \text { banks } \\
\text { needed } \\
\text { capitalizatio } \\
\text { n. } 5 \text { banks } \\
\text { are not } \\
\text { solvent. }\end{array}$ & $\begin{array}{l}20 \text { largest } \\
\text { banks had to } \\
\text { bring to } \\
\text { positive } \\
\text { value the } \\
\text { capital } \\
\text { adequacy } \\
\text { ratio. }\end{array}$ & $\begin{array}{c}\text { The NBU } \\
\text { imposed on } \\
\text { banks } 15 \\
\text { fines }>67.6 \\
\text { million } \\
\text { UAH. }\end{array}$ & $\begin{array}{c}13 \text { banks needed } \\
\text { capitalization of } \\
42.1 \\
\text { billion UAH } \\
\text { under the } \\
\text { adverse } \\
\text { scenario. }\end{array}$ & - \\
\hline $\begin{array}{l}\text { Liquidated } \\
\text { banks }\end{array}$ & 33 & 32 & 22 & 9 & 1 & - \\
\hline
\end{tabular}

Source: compiled by the authors according to the ST source (NBU). 
According to the historical retrospective data, in the formation of the strategy of banking stress testing in Ukraine two stages of assessing the financial stability of the banking system are distinguished as follows: the first stage - 2014-2017 and the second stage - 2018 to date.

The first stage is characterized by a set of diverse approaches to assessing the financial stability of banks using the basic macroeconomic scenario of stress tests. For the first time, the banking system for assessing the financial sustainability of banks began to analyze not only the banks' compliance with banking standards, but also to assess the macroeconomic environment. The specific features of this stage were significant fluctuations in the number of banks subject to stress testing, floating dates for assessing the diagnosis of banks, analysis of credit and currency risks. But the most important factor was practical non-disclosure of the results of stress testing for wide public.

The second stage of banking stress testing strategy in Ukraine is linked to the NBU Board Resolution No. 141 as of December 22, 2017, which approved "The Regulations on the Evaluation of the Resilience of Banks and the Banking System of Ukraine" (NBU, 2017). The second stage is characterized by a higher consistency compared with the first stage of the banking stress testing strategy in Ukraine. An annual assessment of the resilience of banks and the banking system of Ukraine initiated by the NBU unified the size of the banks' sample for research, the general approach to selecting auditors, the dates and periods of assessment of diagnosis, macroeconomic scenarios, individual and portfolio stress testing, types of risks analyzed. But the most important was the legislative approval of the publication of the results of stress testing.

\section{CONCLUSION}

Asset quality assessment and stress testing are a permanent practice of leading international financial organizations. It provides an opportunity to prevent excessive accumulation of systemic risks and prepare banks for possible future crises.

The study of specific features and approaches to stress testing of banks in Ukraine with comparison worldwide practice, permitted to identify the following aspects of formation of the strategy of banking stress testing:

- Stress testing methodology developed by the NBU in accordance with the implementation stages of Basel III recommendations and similar to the EU system.

- Stress testing models, results and frameworks should be reviewed regularly in accordance with the worldwide best practices, especially United Kingdom, Switzerland.

- Stress testing results should be made public and used as a risk management tool and an instrument of informing about business decisions.

Reliable and detailed information on banks' resilience via stress tests can help anchor market assessment of banks, provided that comprehensive and sufficiently severe adverse scenarios are used. Combined with robust follow-up for banks that do poorly in the stress test and credible and well-funded support tools, disclosure can make stress tests useful tools for respond to a crisis.

The conclusions and proposals received on the basis of the study of Ukraine's and worldwide experience will not only improve the financial stability of Ukrainian banking system, but ultimately contribute to overall financial stability.

\section{REFERENCES}

Bank for International Settlements (2009). "Principles for sound stress testing practices and supervision". Available at: http://www.bis.org/publ/bcbs155.pdf (accessed 07 October 2019).

Bank of England (2017). "Stress testing the UK banking system: 2017 results". Available at: https://www.bankofengland.co.uk/-/media/boe/files/stress-testing/2017/stress-testing-the-ukbanking-system-2017-results (accessed 07 October 2019). 
Ramskyi, A., Sobolieva-Tereshchenko, O. and Zharnikova, V. (2019) "Comparison worldwide and Ukrainian practice of bank stress testing”, Management and entrepreneurship: trends of development, 4 (10), pp. 19-28. Available at: https://doi.org/10.26661/2522-1566/2019-4/10-02

Bank of Japan (2017), "Macro stress testing in the financial system report". Available at: https://www.boj.or.jp/en/research/brp/fsr/data/fsrb170421a.pdf (accessed 07 October 2019).

Basel Committee on Banking Supervision (2011). "Basel III: A global regulatory framework for more resilient banks and banking systems". Available at:https://www.bis.org/publ/bcbs189.htm (accessed 07 October 2019).

Breuer, T., Mencia, J., Jandacka, M. and Summer, M. (2010). "A Systematic Approach to MultiPeriod Stress Testing of Portfolio Credit Risk", Journal of Banking \& Finance, issue 2(36), pp. 332-340.

NBU (2019). "Description of stress testing banks in 2019". Available at: https://old.bank.gov.ua/control/uk/publish/article?art_id=89024933 (accessed 07 October 2019), (in Ukrainian)

Decree of Board Of National Bank Of Ukraine (2017) "On approval of Regulation on carrying out of assessment of stability of banks and banking system of Ukraine". Available at: https://zakon.rada.gov.ua/laws/show/v0141500-17 (accessed 07 October 2019), (in Ukrainian)

Board of Governors of the Federal Reserve System (2016). "Dodd-Frank Act Stress Test 2016: Supervisory Stress Test Methodology and Results", [Online], (in English), available at: https://www.federalreserve.gov/newsevents/pressreleases/files/bcreg20160623a1.pdf (Accessed 07 October 2019).

Frame, W.S., Gerardi, K. and Willen, P. (2015). "The Failure of Supervisory Stress Testing: Fannie Mae, Freddie Mac, and OFHEO", SSRN Electronic Journal. Available at: http://dx.doi.org/10.2139/ssrn.2637090 (accessed 07 October 2019).

Hirtle, B. et al. (2016). "Assessing financial stability: The Capital and Loss Assessment under Stress Scenarios (CLASS) model”, Journal of Banking \& Finance, 69, pp.S35-S55. Available at: http://dx.doi.org/10.1016/j.jbankfin.2015.09.021 (accessed 07 October 2019).

Kapinos, P.S., Mitnik, O.A. and Martin, C.A. (2015). „Stress Testing Banks: Whence and Whither?", SSRN Electronic Journal. Available at: http://dx.doi.org/10.2139/ssrn.2710846 (accessed 07 October 2019).

Krykliy, O. et al. (2018). "Model of Stress-testing of Banks' Liquidity Risk in Ukraine", Financial Markets, Institutions and Risks, issue 2 (2), pp.123-132. Available at: http://dx.doi.org/10.21272/fmir.2(2).123-132.2018 (accessed 08 October 2019).

Posohov, I.M. and Khodyrieva, O.O. (2018). "Stress-testing as the actual tool of risk management in the modern banking system of Ukraine", Financial and credit activity: problems of theory and practice, 1(24), pp.53-62. Available at: http://dx.doi.org/10.18371/fcaptp.v1i24.127803 (accessed 08 October 2019), (in Ukrainian).

Ramskyi, A., Loiko, V., Sobolieva-Tereshchenko, O., Loiko, D., and Zharnikova, V. (2017). "Integration of Ukraine into the European banking system: cleaning, rebooting and Basel III", Journal of Banks and Bank Systems, issue 12(4), 163-174. Available at: http://dx.doi.org/10.21511/bbs.12(4-1).2017.05 (accessed 07 October 2019).

Wall, L.D. (2013). "Measuring Capital Adequacy Supervisory Stress Tests in a Basel World", SSRN Electronic Journal. Available at: http://dx.doi.org/10.2139/ssrn.2579897 (accessed 08 October 2019).

\section{СПИСОК ВИКОРИСТАНИХ ДЖЕРЕЛ}

Bank for International Settlements (2009), "Principles for sound stress testing practices and supervision”, URL: http://www.bis.org/publ/bcbs155.pdf (дата звернення: 07.10.2019).

Bank of England (2017), "Stress testing the UK banking system: 2017 results", URL: https://www.bankofengland.co.uk/-/media/boe/files/stress-testing/2017/stress-testing-the-ukbanking-system-2017-results (дата звернення: 07.10.2019).

Bank of Japan (2017), "Macro stress testing in the financial system report", URL: https://www.boj.or.jp/en/research/brp/fsr/data/fsrb170421a.pdf (дата звернення: 07.10.2019). 
Basel Committee on Banking Supervision (2011), "Basel III: A global regulatory framework for more resilient banks and banking systems", URL: https://www.bis.org/publ/bcbs189.htm (дата звернення: 07.10.2019).

Breuer, T., Mencia, J., Jandacka, M. and Summer, M. (2010). "A Systematic Approach to MultiPeriod Stress Testing of Portfolio Credit Risk", Journal of Banking \& Finance, issue 2(36), pp. 332-340, (in English).

НБУ. Національний банк оприлюднив підхід до стрес-тестування банків у 2019 році. URL: https://old.bank.gov.ua/control/uk/publish/article?art_id=89024933 (дата звернення: 07.10.2019).

НБУ. "Про здійснення оцинки стіікості банків і банківськи системи України”, URL: https://zakon.rada.gov.ua/laws/show/v0141500-17 (дата звернення: 07.10.2019).

Board of Governors of the Federal Reserve System (2016), "Dodd-Frank Act Stress Test 2016: Supervisory Stress Test Methodology and Results", URL: https://www.federalreserve.gov/newsevents/pressreleases/files/bcreg20160623a1.pdf （дата звернення: 07.10.2019).

Frame, Scott, Kristopher Gerardi, and Paul Willen (2015). "The Failure of Supervisory Stress Testing: Fannie Mae, Freddie Mac, and OFHEO”, URL: https://www.frbatlanta.org/research/publications/wp/2015/03.aspx (дата звернення: 07.10.2019).

Hirtle, B. et al. (2016). "Assessing financial stability: The Capital and Loss Assessment under Stress Scenarios (CLASS) model”, Journal of Banking \& Finance, 69, pp.S35-S55. Available at: http://dx.doi.org/10.1016/j.jbankfin.2015.09.021 (accessed 07 October 2019).

Beverly, H., Kovner, A., Vickery, J., and Bhanot M. (2016). "Assessing financial stability: The Capital and Loss Assessment under Stress Scenarios (CLASS) Model”, Journal of Banking and Finance, issue 69, pp.35-55. (in English).

Kapinos, P., Oscar M., and Christopher M. (2018). "Stress Testing Banks: Whence and Whither", Journal of Financial Perspectives, issue 5(1), pp. 68-87. (in English).

Krykliy O., Luchko I., (2018). "Model of Stress-testing of Banks' Liquidity Risk in Ukraine", Financial Markets, Institutions and Risks, issue 2 (2), pp.123-132 (in English).

Посохов I. М., Ходирєва О. О. Стрес-тестування як актуальний інструмент ризик менеджменту сучасної банківської системи України. Фінансово-кредитна діяльність: проблеми теорії та практики. 2018. Вип.24. С. 53-61.

Ramskyi A., Loiko V., Sobolieva-Tereshchenko O., Loiko D., and Zharnikova V. (2017). "Integration of Ukraine into the European banking system: cleaning, rebooting and Basel III", Journal of Banks and Bank Systems, issue 12(4), 163-174, URL: http://dx.doi.org/10.21511/bbs.12(4-1).2017.05 , (дата звернення: 07.10.2019).

Wall, Larry (2014). "Measuring Capital Adequacy: Supervisory Stress-Tests in a Basel World". Journal of Financial Perspectives, issue 2(1), pp. 85-94. (in English).

\section{ПОРІВНЯННЯ СВІТОВОЇ Й УКРАЇНСЬКОЇ ПРАКТИКИ БАНКІВСЬКОГО СТРЕС ТЕСТУВАННЯ}

\section{Рамський Андрій} Юрійович

Університет Бориса Грінченка Київ, Україна

\section{Соболєва-Терещенко Олена}

Анатоліївна

Університет Бориса Грінченка

Київ, Украӥна

\author{
Жарникова Валерія \\ Владиславівна \\ Киӥвський національний \\ торгово-економічний \\ університет, Київ, Украӥна
}

Перші стрес-тести, які використовувалися переважно в якості інструментів управління ризиками, датуються 1990-ми роками. Програми, впроваджені МВФ, Банком Англії, Законом Додда-Франка, Банком Японії, Швейцарським органом з нагляду за фінансовим ринком i 
Ramskyi, A., Sobolieva-Tereshchenko, O. and Zharnikova, V. (2019) "Comparison worldwide and Ukrainian practice of bank stress testing”, Management and entrepreneurship: trends of development, 4 (10), pp. 19-28. Available at: https://doi.org/10.26661/2522-1566/2019-4/10-02

Світовим банком, сприяли подальшому використанню стрес-тестів. Основна ідея введення стрес-тестування полягала в забезпеченні банків достатнім капіталом для покриття своїх ризиків і зростанні стійкості банків і банківських систем до економічних і фінансових потрясінь. У даній статті узагальнено досвід стрес-тестування регулюючими органами в Сполучених Штатах, Великобританії, Японії, Швейцарії та Європейському союзі. У цій статті також дається огляд методології стрес-тестування, розробленої Національним банком України відповідно до рекомендацій Базель III. Метою дослідження є порівняльна оцінка ключових аспектів загальносистемних стрес-тестів в різних фінансових системах: зоні євро, Великобританії, Швейцарії, Японії, США та України, виявлення подібностей, відмінностей і перспектив подальшого розвитку. Для обгрунтування теоретичних положень і висновків використовуються загальнонаукові методи, в тому числі системний, абстрактно-логічний підхід, а також методи формалізації, аналізу та узагальнення інформації, порівняльний аналіз. В ході дослідження було проведено порівняльний аналіз методології стрес-тестування в шести країнах. Наукова значимість роботи полягає в систематизації передового досвіду стрес-тестування розвинених країн та розробці на їх основі рекомендацій щодо поліпшення методики стрес-тестів банківської системи України. Цінність дослідження полягає в обгрунтуванні необхідності використовувати кращі методи стрес-тестів в якості потужного інструменту управління ризиками в мікропруденціальной і макропруденційних політиці. Результати досліджень можуть бути використані не тільки в розробці методології стрестестування, але і в тематичному дослідженні банківської справи.

Ключові слова: фінансова стійкість, Базель III, основний капітал, регулятивний капітал

\section{СРАВНЕНИЕ МИРОВОЙ И УКРАИНСКОЙ ПРАКТИКИ БАНКОВСКОГО СТРЕСС ТЕСТИРОВАНИЯ}

\author{
Рамский Андрей \\ Юрьевич \\ Университет Бориса \\ Гринченко \\ Киев, Украина
}

\author{
Соболева-Терещенко Елена \\ Анатольевна \\ Университет Бориса \\ Гринченко \\ Киев, Украина
}

\author{
Жарникова Валерия \\ Владиславовна \\ Киевский национальный \\ торгово-экономический \\ университет, Киев, Украина
}

Ранние стресс-тесты, используемые в основном в качестве инструментов управления рисками, датируются 1990-ми годами. Программы, проводимые МВФ, Банком Англии, Законом Додда-Франка, Банком Японии, Швейцарским органом по надзору за финансовым рынком и Всемирным банком, способствовали использованию стресс-тестов. Основная идея введения стресс-тестирования состояла в обеспечении банков достаточным капиталом для покрытия своих рисков и сделать так, чтобы банки и банковские системы были более устойчивыми к экономическим и финансовым потрясениям. В данной статье обобщен опыт недавнего стресс-тестирования регулирующими органами в Соединенных Штатах, Великобритании, Японии, Швейцарии и Европейском союзе. В этой статье также дается обзор методологии стресс-тестирования, разработанной Национальным банком Украины и в соответствии с рекомендациями Базель III. Целью исследования является сравнительная оценка ключевых аспектов общесистемных стресс-тестов в различных финансовых системах: зоне евро, Великобритании, Швейцарии, Японии, США и Украине, выявление сходств, различий и перспектив дальнейшего развития. Для обоснования теоретических положений и выводов используются общенаучные методы, в том числе системный, абстрактно-логический подход, а также методы формализации, анализа и обобщения информации, сравнительный анализ. В ходе исследования был проведен сравнительный анализ методологии стресс-тестирования в шести странах. Научная значимость работы 
состоит в систематизации передового опыта стресс-тестирования развитых стран и разработке на их основе рекомендаций по улучшению методики стресс-тестов банковской системы Украины. Ценность исследования заключается в обосновании необходимости использовать лучшие методы стресс-тестов в качестве мощного инструмента управления рисками в микропруденциальной и макропруденциальной политике. Результаты исследований могут быть использованы не только в разработке методологии стресстестирования, но и в тематическом исследовании банковского дела.

Ключевые слова: финансовая устойчивость, Базель III, основной капитал, регулятивный капитал 